\title{
Country stories: the use of oral histories of the countryside to challenge the sciences of the past and future
}

\author{
DAVID HARVEY* and MARK RILEY† \\ * Department of Geography, University of Exeter, Exeter EX4 4RJ, UK \\ † School of History, University of St Andrews, St Andrews, Fife KY16 9AL, Scotland, UK
}

In the context of recent media, governmental, academic and popular attention and enthusiasm for debates surrounding the construction and meaning of the British countryside, this paper outlines the potential for oral history to make a contribution. Drawing on work in Devon, UK, we outline how an oral history methodology can engage with the fields of archaeological science and heritage management of landscape resources from the past, before outlining how such lay narratives may also inform present policies for the landscapes of the future. On the one hand we note the potential of oral histories for animating existing scientific narratives of landscape development. Moving from a position of scientific complicity towards one of critical engagement, we then go on to argue that oral histories may also challenge the authority of scientific knowledge, serving to destabilise existing assumptions, and offering in their stead more complex, meaningful and community-led narratives of landscape.

Whether in relation to GM food, pesticides and the use of organophosphates; the tragedies of Foot and Mouth Disease and BSE; the convoluted and often acrimonious debates about hunting with hounds; the thorny issue of public access; or the fantasy world of Common Agricultural Policy 'reform', the countryside lies at the very heart of much present-day popular social debate in the UK. To claim that countryside issues are in vogue' is therefore an understatement of some proportion, but tying down the framework of the ever shifting debate is a more difficult proposition. The actions of powerful lobbyists such as the Countryside Alliance, who put great effort into their bid to monopolise the meaning of rural areas in Britain, serve only to highlight the socially constructed nature of such terms as 'countryside' and 'rural'. This instability is also reflected in changes in central government in these areas, exemplified by the transformation of the Ministry of Agriculture, Fisheries and Food (MAFF) into the Department of the Environment, Food and Rural Affairs (DEFRA). The very nature and meaning of the British countryside are thus open to negotiation. But rather than debating the pros and cons of competing countryside meanings in the present, it is our task here to examine how knowledge and narratives of the countryside are constructed within academic and policy arenas. To this end, we explore the potential of oral history both to animate such landscape narratives of the past, and to challenge and problematise the unexamined 'country stories' that have informed present management policies as well as plans for the future form of Britain's rural areas. 
At the heart of this paper is an exploration of how knowledge about rural places, landscapes and societies in the past is constructed in the present, and can inform debates about the future. We contend that reliance upon positivist scientific techniques in landscape investigation provides only a partial understanding of the history of the countryside, and that such one-dimensional knowledge has too often been used to construct a similarly narrow agrienvironmental policy for the future, as 'non-institutional forms of experience and knowledge become systematically deleted from recognition'. ${ }^{1}$ Reliance upon such scientific techniques has led to a premium being placed upon the form of the landscape as an aesthetic object, rather than a socially produced space with multiple levels of construction and meaning. On an academic level, while much comment has been passed on the meaning of the countryside and notions of the 'rural idyll', it seems that the discipline of landscape studies is still largely dominated by scientific methods of physical survey and measurement. ${ }^{2}$ On a policy level, while the rhetoric of government has purportedly moved toward taking 'more account of local knowledge and [being] more locally accountable', scientific knowledge produced by expert informants still holds sway in terms of constructing the countryside of tomorrow. ${ }^{3}$

Working in the area of scientific landscape studies in general, and the negotiation of knowledge construction, interpretation and management of the agricultural landscape in particular, this paper reviews the strength of oral history as an alternative datastream and an underused methodology in the investigation of the British countryside. Although ostensibly about landscape and agricultural changes in Devon, UK during and around the Second World War, the discussion opens up into a much broader exploration of how knowledge about the countryside is constructed, and of the consequences this might have for policy. We begin with a short review of existing narratives of the countryside, both within the discipline of landscape studies and in relation to policy formulation. Moving on to discuss the potential of oral history, narratives of the past development of the landscape are examined, drawing on excerpts from oral history interviews with farmers in Devon to animate, support and sometimes challenge these 'sciences of the past'. Using a case study of hedgerow management, these stories of the past are then used to shed light on the practices of countryside conservation and management of today. Finally, we aim to show how oral histories can be used to inform and indeed challenge the 'sciences of the future', suggesting that we need to view such figures as farmers as knowledgeable rather than ignorant agents in agrienvironmental policy formulation.

\section{EXISTING NARRATIVES OF THE COUNTRYSIDE}

Recent years have seen increasing interest in issues of rural landscape development, with popular enthusiasm strongly fostered by academic attention, the pursuits of landscape archaeologists perhaps being its most high profile public face. Indeed, in the UK 'pop archaeology' programming has become a central feature of both the BBC and independent television broadcasters, following in the wake of the 'groundbreaking' Time Team format. ${ }^{4}$ A common strand, at least in media interest in issues of landscape development, has been continued reliance on the expert interpretation of material artefacts, and associated deference toward scientific research. Although the so called 'cultural turn' has seen a flourishing of work that is sceptical of the scientific objectivity of such an approach to landscape studies, a metanarrative of scientific landscape archaeology has come to dominate the public face of academic landscape study. The lines of questioning are expert led, and 
revolve around the derivation of the countryside as a physical artefact - conceiving the integrity of the landscape in terms of a linear narrative that can be revealed by expert interpretation and a singular and verifiable truth. Rather than being socially constructed and 'situated', knowledge, in this system, is the preserve of the 'expert'.

Turning to the arena of policy formulation, one can sense a transition, at least in terms of rhetoric, with a stronger emphasis on the role of culture and society in the management of the countryside being recognised. In terms of the evidence base for policy decisions however, positivist science appears still to hold sway. The threat of audit trails and the perceived need to legitimate decisionmaking with reference to 'solid fact' have surely contributed to the gap between the cultural rhetoric and the generation of a scientific knowledge base. However, some degree of inertia would seem inevitable as, on the one hand, policymakers who have been classically trained in positivist science struggle to recognise social complexity and nuance amid a multiply constructed countryside, while on the other, advocates of subjective and qualitative methods drawing heavily on feminist theory have perhaps paid more attention to conversing with other academics, than to trying to convince the policymakers.

We conducted in-depth semistructured interviews with thirty-three people in relation to landscape change in the period during and after the Second World War. In particular, attention was paid to the wartime 'Plough-Up' campaign, which acted as a meaningful prompt that would immediately be recognised by people working the land at that time. As well as using these personal narratives to assess the nature of some of the official records from the period and to explore the detail of the events associated with the Plough-Up, we were also interested in farmers' more general experience of changing countryside management practice and experience. In particular, we investigated the extent to which the information they provided could help both to animate and indeed destabilise conventional linear narratives of the development of the agricultural landscape, and also to challenge the assumptions behind, and add nuance to, the formulation of agrienvironmental conservation policies for the future. It is to these areas that we now turn.

\section{AUGMENTING AND CHALLENGING THE SCIENCES OF THE PAST}

This section of the paper draws on oral history material from the interviews, examining their implications with respect to existing approaches used in landscape studies, reviewing the extent to which oral historical knowledge may both enhance and support other lines of inquiry, but also problematising and challenging the veracity and meaning of other strands of knowledge.

\section{Disruption of environmental scientific narratives of the past}

Farming was in a terrible state you see. Landlords couldn't get people to farm the land ... they simply couldn't give it away. I remember a field next to our farm being planted with furze. ${ }^{5}$ I don't know how ever they got the seeds or whatever to do it, but they did. They planted it and after the first year they clipped the shoots to make it grow out, more bushy like.

[Why was that?]

For fox cover. Cover to attract the foxes in for shooting. That shows what the land was worth, they preferred to plant furze because the sport was more important. It didn't last long, but they definitely did it 
Ostensibly, this extract from an interview with an eighty-eight year old farmer appears to be an anecdotal account with little relevance for the scientific reconstruction of past landscapes. By implication, however, this story of deliberate planting of gorse in the late 1930s carries an important message for how we utilise such scientific techniques as pollen analysis, which has been widely employed by environmental and landscape archaeologists. ${ }^{6}$ While useful in identifying broad scale changes over long time periods, pollen analysis is unable to account for such rapid and seemingly anomalous changes in landscape as those the farmer in the above extract reflects on. Indeed, the usual poor state of preservation that is normally associated with gorse pollen would almost certainly result in the practices to which the farmer refers being completely missed by such a technique; and even if the pollen signature were to be picked up, deliberate gorse planting would almost certainly be discounted as an explanation. In the absence of any other source of information, from pollen analysis of such a site it could therefore be logically argued that such gorse 'encroachment' reflected a period of abandonment and reversion of once 'productive' land.

On one level, therefore, the oral history disrupts such narratives, highlighting the transient and arguably 'illogical' nature of the action. More importantly, however, the oral history extract takes such scientific techniques as pollen analysis a step further, by illuminating the subjective and culturally contextualised terrain surrounding the farmer's process of decisionmaking. The oral history tells a story of desperation, whereby the farmers' actions adapted to suit the immediacy of changing circumstances, thus enlightening and providing a context for this temporary change. Oral history does not necessarily refute the data provided by the scientific technique of pollen analysis. Rather, it provides an account that has more detail and nuance, a construction of knowledge which is responsive to particular, seemingly 'illogical' and even temporary conditions, and which is deeply embedded within cultural circumstance.

Taking a further step back, however, while the discipline of landscape studies often talks in terms of temporally linear landscape 'transitions' (such as 'from the Palaeolithic to the Mesolithic' or 'from feudal to capitalist') that are based upon rational analysis, this example highlights the messiness associated with any such transition in landscape use, form and meaning. Although well beyond the scope of direct oral history collection, therefore, this example suggests that it may be wrong to portray episodes such as the 'agricultural revolution' or the 'introduction of the enclosure movement' as one-dimensional linear transitions. Indeed, within the context of post-war landscape change, this example highlights the complexity and untidiness covered up if this period is described simply in terms of a generalised 'transition from productivist to post-productivist countryside?.'

It is not the role of oral history necessarily to overturn the results produced by scientific techniques such as pollen analysis. As Alan Irwin has suggested, "[t]he point is not to sweep aside one knowledge form and replace it with another. Instead, we need to recognise the contextual and partial nature of all ... forms of understanding. ${ }^{8}$ In this vein, oral history provides material that adds depth and sophistication to scientific knowledge, while also providing a warning against constructing too simple a landscape narrative from scientific data. Landscape narratives may turn out to be partial, temporary, even seemingly illogical, and occurring outside the neat linear temporal frameworks that are often used to explain the countryside. 
On other occasions, however, oral histories can reveal certain lines of evidence to be misleading or simply wrong. Following is one such example, involving written archives relating to the management of agricultural production in Second World War Britain.

\section{Disruption of official archival narratives}

As the traditional source material for historians, written archives have long been used to form the central narrative of many stories of the countryside. Although the degree to which historians have ever regarded their pursuit as entirely 'objective' can be questioned, recent trends toward taking a more critical line when dealing with archival source material, and to seeing their production as contingent and an inherently political exercise are certainly encouraging. However, reliance on, and acceptance of, the factual veracity of certain archival sources, particularly those of an 'official', statistical or 'factual' nature is still largely uncontested, ${ }^{9}$ as is the criticism of some unreflective historical analysis, where the written archive may be 'fetishised' as the only means by which an 'accurate' narrative of the past may be constructed. ${ }^{10}$ Raphael Samuel for instance argued that academic training predisposes us to privilege the written word, and to hold the visual and the verbal in comparatively low esteem, adding that 'modern conditions of research seem to dictate an almost complete detachment from the material environment. ${ }^{11}$ Despite such concerns, however, much of what we understand about the history of the landscape and landscape change in Britain flows from 'official' historical documents.

As an example of how oral history can destabilise official textual narratives, we now discuss the National Farm Survey (NFS), conducted as part of the war effort in the UK between 1941 and 1943. The survey offers the most detailed information available at the farm scale, and has been referred as a 'new doomsday'. ${ }^{12}$ It holds information on issues of ownership and resources, and, more unusually, contains a grading of farms as 'A', 'B' or ' $\mathrm{C}$ ' in relation to their layout, type and how they were perceived to have been managed. Often, the lowest grading of ' $\mathrm{C}$ ' was given to farms for reasons such as 'farmer lacks ambition', 'drunkard' or even 'this farmer is a woman'..$^{13}$ Details from individual farm records and the accompanying farm maps were used as a prompt for discussion during our project's oral history interviews. It was found that many farmers disputed the official record of the government survey, in terms of its detailed content, but also in terms of its implied championing of narrow economic and productivist aims.

Figure 1 shows an excerpt from one of the maps held as part of the official NFS archive, which was discussed with the farmer of the mapped holding during interview. The oral history of the seventy-four year old farmer, whose family had lived on the farm for a hundred and thirty years, challenged the authority of the NFS as a historical record. As part of the discussion and recollection of the farmer, two examples were noted where the boundary had been mapped incorrectly in the survey:

We've got a boundary wrong here [see area 1 in Fig. 1], that boundary should be up there. That field isn't mine ... That was Shaw's field next door ... they have owned that for over a hundred years...

This bit [see area 2 in Fig. 1] was kept back when father bought it. They'd thrown a lot of timber there and in pulling out all the timber had broken all the drains, and father being fairly hot-headed said unless they put the drains right he wouldn't buy it . . . and they haggled over it for a while and they wouldn't put the drains right so father said you keep it. 


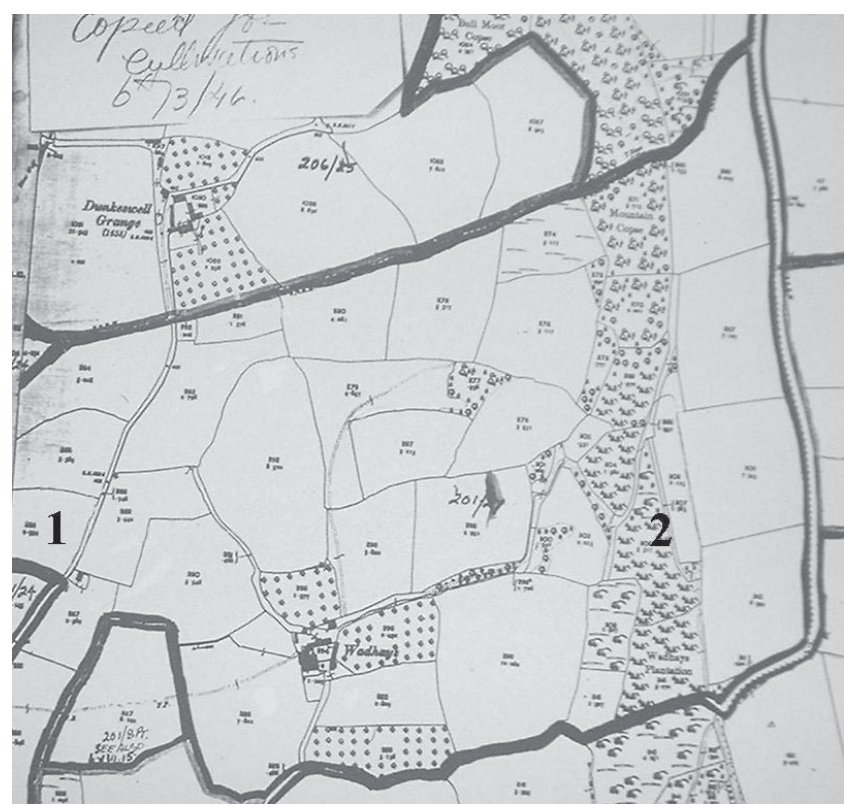

1 Extract from the National Farm Survey (1941-43)

On one level therefore the testimony of the farmer shows the 'official' record to be simply wrong. On another level, the issue is not just to do with lines on a map, but with eliciting people's stories and recollections about the landscape - considering how they remember and interpret things. There has been much criticism in the past of the use of oral history on grounds of its unreliability, as memories are inevitably relayered and there is never 'pure' recall. However, we would argue that in this instance the performance and rehearsal of memory is actually a strength of oral history. Here the farmer knows that the boundary has remained constant over a period of years, and he and his family's biographical events intersect with and reinforce this knowledge.

The challenge made by oral history to the NFS goes beyond the physical features it mapped, taking in also the enduring statements that it overtly and implicitly makes about agriculture in the period. In relation to ownership details of holdings, a number of respondents pointed to the deliberate splitting of holdings in order for younger men to avoid conscription. One farmer for example spoke of his father 'breaking the farm into three lots' and providing each of his sons with a rent book, so that they would avoid conscription to serve in the war. So while the official documentation of the time reveals a predominance of tenanted farms over owner occupation, the oral histories reveal that such figures may be artificially inflated.

A further, more contentious, issue arose in discussing the gradings made by the officials completing the survey. Commonly, the oral histories offered an alternative narrative to the pejorative labels attributed by scheme officials. The following extract is from an interview with a retired farmer who questioned the notion of 'ambition':

But you see, a lot of them, they were farming to live and they didn't want very much [They would say] 'We don't want any money, we've got enough to live as we are' ... To other people it looks like a lack of ambition, but he'd say 'What do I want to do all that for? I got enough money to live on; I can pay my bill at Matthews.' They didn't lack ambition; they were just meeting their needs. 
Such extracts lead us to an appreciation of how histories must be understood in context. For example, while the official NFS archive suggests that certain farmers 'lacked ambition', the definition of ambition was one narrowly constructed around economic and production priorities resulting from war. The oral histories offer us an alternative narrative which helps furnish such archives with social, economic and cultural understandings that may otherwise be missed, misrepresented or glossed over in a historical narrative based entirely upon written archives.

\section{Disruption of archaeological narratives}

This greater sense of reflexivity within oral history approaches has been mirrored by a wider recognition in recent years of its potential to reach beyond the notion that there is a single, 'truthful' historical narrative to be uncovered. ${ }^{14}$ Indeed, as Allan Nevins suggests, oral histories allow us some degree of entry into 'the structure and variety of a society or culture, as manifested by an individual's world view, cultural traits and traditions'. ${ }^{15}$ In other words, they help us co-construct the landscape through people's contextualised recollections of a particular place - what Patricia Partnow has described as 'linguistically appropriating the landscape ${ }^{36}$ The following extract is taken from an interview with a ninety year old farmer who was asked about historical features on his land:

They tell me we've got burial mounds. They've been to look at it . . . and it's been mapped out. We used to use it to load the cows for market. It's sloped up you see, so we used to back the lorry up to it and run the cows into the lorry.

The mound in question had been 'discovered' by archaeologists in the 1990s. The site was rigorously measured, carefully surveyed and recorded as a 'burial mound', thought to be of Bronze Age origin. For the normative, positivist and artefact-centred record, a new dot could be placed on a map, a set of measurements and ground survey data recorded on the Sites and Monuments Register, and a heritage management plan be established for the site's preservation for posterity. However, to claim that the site had not been previously known is only correct within the narrow confines of the academic and statutory archaeological and landscape records. At least one person had known about the mound all his life - the farmer on whose land it was situated. Previous work on 'Bronze Age burial mounds' in this part of the country has focused on their relationship to early boundaries for instance; their use as cattle ramps and for other such purposes has remained mysteriously off the official heritage and archaeological records. ${ }^{17}$

This case of a Bronze Age burial mound/cattle ramp in Devon may appear both marginal to landscape study, and positively destructive in terms of heritage management. However as Sian Jones notes, it is important to recognise the value of narratives that are not strictly 'correct': they may reveal a great deal about an individual's relationship with a historical site, as well as about how knowledge of a site or landscape more generally is used by interested individuals and groups. ${ }^{18}$ In this case, the farmer's interpretation of the 'burial mound' was not in a scientific sense 'correct', but it was nevertheless full of meaning, which was not restricted to the obvious agenda of archaeological science. This reminds us of the importance of appreciating the metaphorical, symbolic, ironic and other connotative meanings which are a dynamic and often contradictory part of everyday life. ${ }^{19}$

At the level of interpreting the physical landscape, the use of the 'burial mound' as a cattle ramp has undoubtedly affected the feature's form. Ironically however, the mound's 
value as a cattle ramp may well have secured its physical integrity, since as an unrecorded site it could well have been 'legitimately' mechanically flattened or ploughed out, had the farmer not found a use for it. For the farmer, the value of the mound was as an aid to loading cows onto a lorry, not in any historical, aesthetic or 'heritage' significance. In order to account for the site's 'preservation', we should acknowledge the economic value of burial mounds for such purposes as cattle management, thereby acknowledging the full 'life history' of the mound/ramp. ${ }^{20}$ As with any landscape, a biographical approach reveals successive, sometimes competing interpretations, indicating that any present-day heritage management practices should recognise not one mound, about which only one (scientifically authenticated) story can be told, but several, representing multiple narratives - some scientifically 'correct' and others personal, ironic or symbolic.

The burial mound example leads naturally into consideration of a number of more general issues that are of relevance to countryside management. In making space for a farmer's personal narrative, questions over the nature of what such terms as 'landscape' and 'heritage' represent are opened up. The mound calls us to interrogate how knowledge about the countryside is normally constructed; for an examination of how such knowledge is normally categorised; and for an exploration of how different categories of knowledge are generally valued - by experts, policymakers and the wider public.

\section{AUGMENTING THE SCIENCES OF THE FUTURE}

We will turn now to look at how an oral history approach may inform and challenge ideas surrounding the future of the countryside. Many current attempts at landscape and nature conservation are concerned with encouraging 'traditional' management practices, with the Countryside Stewardship Scheme for example carrying the slogan 'traditional farming in a modern environment'. ${ }^{21}$ Our work in Devon has led to a problematisation of what may be called 'traditional' practice, with oral histories of hedgerow management forming a particular focus. The 'traditional' Devon hedge is a feature that is often considered to have gone unchanged for centuries, and yet we have found that these 'traditional' hedges are an invention - if not always in form, then certainly in meaning.

Current conservation efforts encourage replanting and (so called) traditional management of hedgerows, implying that the landscape immediately before the post-war period of hedgerow removal was a golden age of unchanging 'tradition'. Several of our respondents, however, commented that hedgerows were either not managed very carefully in the past, or were managed within the context of a practice that is now non-existent:

Father and grandfather said hedging didn't pay, so they just left them, so when I took over they had seventy or eighty years growth on ... They are definitely in better order than they have been for a hundred years, more than a hundred and fifty I expect.

This comment from a seventy-nine year old farmer directly challenges the idyllic narrative of hedgerow maintenance being part of a premechanised countryside 'tradition', begging the question what 'traditional practice' really means, and forcing us to consider the meaning that is conveyed by present-day conservation practices. In many ways, such current practices as 'traditional hedgelaying', heavily subsidised through government grants, should be recognised as partially invented traditions to be understood within the context of present-day agendas, wants and hopes for the future. ${ }^{22}$ The idea of having hedges in the 
landscape is certainly not 'brand new', but hedges are more than just one-dimensional physical objects. Hedges have a history, and their dynamic record of management, destruction and upkeep reflects changing attitudes and meanings associated with them. The practice of hedgelaying for the purpose of constructing an ecoconservation-minded aesthetic object is both fairly new, and also a reflection of present-day landscape heritage concerns - albeit concerns that are widely supported through academic rationale, public sympathy and government funding.

While there are many excellent present-centred reasons for such hedgerow management, including floral and faunal conservation and biodiversity, as well as protection of slopes from soil erosion and crops/livestock from the weather, the lack of deeper social context in hedgerow management is further supported by more oral history:

The hedges would be trimmed and faggots would be used for kindling. Then the trimmings would be gathered up and thrown under the ricks. It all tied in you see? You cleared the field and then trimmed the hedges to lay under the ricks as you built them. It kept the rick up off the floor you see? Stopped it from getting damp.

In this case, rather than laying hedges for the sake of any romantic idea of 'tradition' or the maintenance of bucolic views, hedgelaying is set within the context of wider farming practice. ${ }^{23}$ For this eight-one year old farmer, making good hay demanded a certain system of hedgerow management. As well as highlighting the fact that the history of hedgerow management is one of multiple narratives, with hedges meaning different things to different people, and having different purposes in different areas, even down to the level of the individual farm, this oral history emphasises the role of hedges as an essential part of a particular system of farming. With wider agricultural trends moving towards silage production rather than haymaking, one of the fundamental meanings of hedgelaying changes. The intention here is not to comment on the ethics, or indeed the efficacy, of either hedgerow destruction or management under conservation schemes. Rather we are seeking to make space for alternative narratives of hedgerow management - narratives that can challenge some of the thinking behind such practices, as well as inform the construction of a more holistic management policy for Britain's landscape.

This need to recognise the wider context and meaning of such landscape features as hedges is well illustrated in the following oral history example from a seventy-eight year old farmer:

They'd got their certain field which they knew would grow good wheat, good barley, good oats, ... and it was all done on a seven year system.

If you said you were going to plough a certain field on your farm, starting, say, from October, whatever wood that was on the hedges would be cut and used for firing. The hedge would be reinstated as a Devon hedge because there would be turf in the field wouldn't there? And you would be allowed to use any turf out of that field because it was going to be ploughed see? And you reinstated your banks.

Then the field would be ploughed before Boxing Day that autumn, and in January, if they wanted spring wheat, he was tilled in January. If not, he was tilled late February, early March for oats and barley and then the following year he would go into winter wheat, which would be tilled in November.

$[\ldots]$

INTERDISCIPLINARY SCIENCE REVIEWS, 2005, VOL. 30, N0. 1 
The winter wheat would come off in early July, but then he would be reploughed and put to what we call 'sheep's meat', which is kale, swedes, turnips. Then you'd have two years of barley - that's five years. The sixth year would be oats, and the last year again would be barley with grass seeds undersown on it. In that seven years your hedge would have chance to regrow from where it was laid and that. He would be nice and thick wouldn't he? And you'd get a nice stock proof hedge out of that. ... You also had a crop for firing.

So the hedge would be managed with the field in the rotation. ... On a farm of, say, a hundred and fifty acres, there would be two or three fields done each year. . . It was kept as manageable - an ordinary man could do the job all yourself.

This outline of a seven year rotation system demonstrates how involved and multidimensional the landscape is: in trying to 'preserve' the physical face of the countryside, we are completely altering the meaning of its features. The above example highlights how hedgerow management fitted into a wider system of agriculture that is now redundant, and in doing so makes something of a mockery of the practice, very common today, of laying a 'traditional' hedge and protecting it with an electric or barbed wire fence (Fig. 2). Rather than seeing the removal of hedgerows as a simple product of mechanisation and the postwar drive towards national self-sufficiency, oral histories reveal some of the diversity and balance of factors at work within the landscape. ${ }^{24}$ Consequently, the present concern for

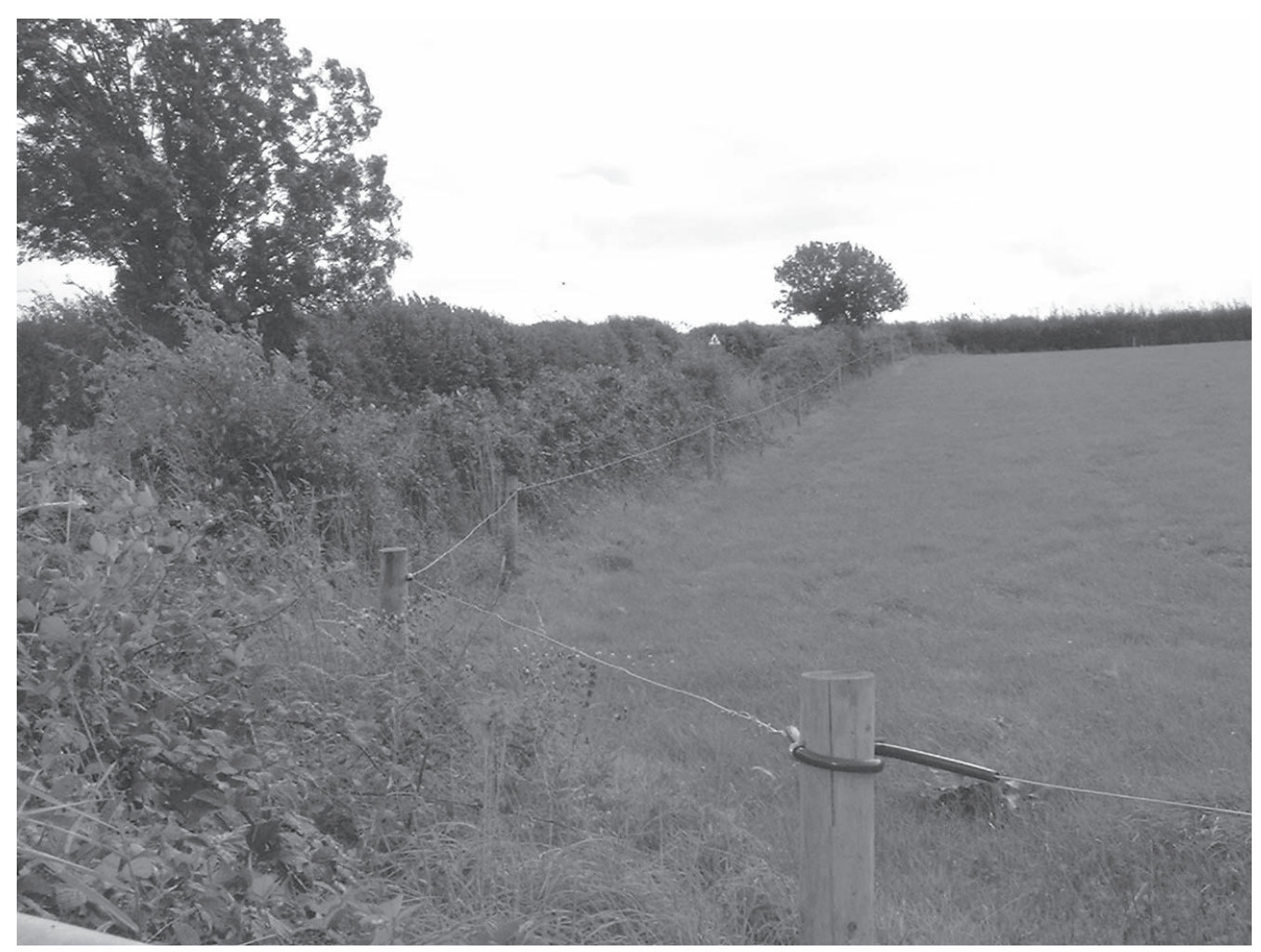

2 Modern managed hedge protected with an electric fence: embedded into a seven year rotation system as described in the text, these hedges would not need electric fencing to make them stock proof

INTERDISCIPLINARY SCIENCE REVIEWS, 2005, VOL. 30, N0. 1 
hedgerow replacement should likewise be viewed within the wider context of the British countryside going through a period of change in terms of its meaning and purpose.

The neatly and newly laid hedge protected by a wire fence has no meaning or purpose within a seven year crop rotation system, but makes perfect sense in the present climate of countryside and environmental management. The oral history examples, however, reinforce a level of scepticism towards the 'one size fits all' approach that is so common in present-day agrienvironmental policies. The UK's Countryside Stewardship Scheme offers incentive payments to landowners where hedgerows 'can be restored by management that follows traditional practices, reflects local customs [and] uses local materials', with more specific objectives to 'regenerate hedgerows and hedge trees by laying, coppicing and planting where these are mismanaged, overgrown or over-trimmed, and re-plant along old hedge lines'. ${ }^{25}$ It is clear that within these management prescriptions hedges have been reinterpreted in terms of their aesthetic and ecological value, with little reference to any functional value and how this may impact on their development, location and form. This enthusiasm to 'museumify' the landscape should be recognised as a present-centred concern, the latest construction of the countryside's meaning and purpose, while policies aimed at the one-dimensional (re)introduction of 'traditional' or 'ancient' practices should be seen as a search for the Holy Grail.

The reinterpretation of hedges as aesthetic objects, outside the realm of active agricultural production, brings with it further problems, confusions and ambiguities. In much of the countryside, hedges are now beyond the agriculturally productive area and are increasingly protected by barbed wire fences, to be preserved in the interests of biodiversity and picture postcard manufacturers. In many respects, therefore, despite the rhetoric of fostering 'traditional agricultural practice', hedges are emphatically no longer 'agricultural objects'. There is a certain mismatch between the championing of biodiversity and the fostering of 'traditional agricultural practice' - the two do not necessarily mix. In addition, paradoxically policies of hedgerow 'protection and enhancement' may actually foil some farmers' attempts to integrate their hedges into a meaningful system of agricultural management. There is a strong sense of irony in the fact that, in certain cases, hedgerows are now out of bounds to farmers who wish to participate in such schemes as Countryside Stewardship: behind barbed wire, such hedges are not to be touched, tainted or brought into any functional agricultural practice.

\section{CONCLUSIONS: A MANIFESTO FOR FUTURE WORK}

With reference to hedgerows, there has been almost universal decryal of their destruction and removal, together with the attendant decrease in both floral and faunal species and the homogeneity of prairie-like landscapes of production. Many books, pamphlets and academic papers document the extent of this destruction, often relaying the extent of such activities in terms of thousands of miles per year of hedge removal. ${ }^{26}$ Related to, and very much stemming from, this sense of regret and loss is a present concern for hedgerow protection - of celebrating a species-rich habitat, and of active 'reinstallation' of hedgerows as an important element in a vision of the future countryside that is apparently more environmentally friendly and socially sustainable in its form. In rushing forward with this laudable agenda however, we need to take stock of the meaning of hedges - in the past, present and future. Hedges should not be seen as one-dimensional aesthetic objects, with a singular narrative and uniform agricultural or ecological function. Indeed, the multiple histories and 
dating of hedges is something that is often glossed over within both popular representations and policy formulations of hedgerow maintenance. For instance, far from having a uniform history of apparent ancientness, in many parts of the country the building and expansion of hedges during the eighteenth and nineteenth centuries was a new form of field division, a reflection of the loss of common rights and the expansion of capitalist exploitation of the land that came with processes of parliamentary enclosure. ${ }^{27}$ Hedges, in this sense, can sometimes be the epitome of modern capitalist agricultural production the latest and most (socially) destructive form of landscape development in their day.

In terms of the meaning of hedgerows today, our oral histories have brought into sharp light the inevitable present-centredness of all such heritage practice. ${ }^{28}$ The act of conservation involves action (or inaction) that is contingent on the agendas of the here and now, and we should recognise that in our efforts to 'preserve' a historic landscape, we are in fact constructing a new countryside, the meaning of which is divorced from its previous social, economic and cultural context. This is not something that should necessarily raise anxiety - indeed the maintenance of any socioeconomic status quo is often as unwanted as it would be impossible to achieve. Rather, we should acknowledge the importance of subjective, local and complex variety and diversity in meaning and practice, lest we end up producing a uniformly sterile museum to posterity - the countryside as a living monument to its own demise. ${ }^{29}$

Looking to the future, we should ask ourselves what we would like our countryside to be like - in terms of both physical presence and meaning. This itself raises the deeper question of how we would like to be remembered through the form of the countryside that is handed on to future generations. Do we want to be remembered as a society for whom nostalgia and regret formed the central framework for our attempt to turn the countryside into a museum that conveys an agreed and singular story? Or do we want to be remembered as a society that attempted to reconcile a myriad competing views, experiences, stories and meanings within a complex and multifaceted countryside? Rather than smugly congratulating ourselves for seeing the error in our (previously destructive) ways, and switching our policies from hedgerow removal to uniform hedgerow conservation, we should take a step back and explore the full variety and diversity of hedgerow meaning. To this end, an oral history approach is invaluable in highlighting the personal, the ambiguous, the complex and seemingly implausible. Rather than simply charting the demise of hedges during the post-war period, for instance, oral histories can paradoxically be used to explore why certain hedges were, sometimes actively, not removed. A narrative of profit-chasing production and high speed mechanisation simply cannot account for the experience of hedgerow management in post-war Britain, while negotiation of (and resistance to) post-war agrienvironmental policy on the part of farmers has been almost entirely ignored by both popular and academic commentators. Farmers were not economically rational automatons, carrying out the wishes of 'The Ministry' without question. Rather, they negotiated, challenged, reconfigured and destabilised official policy to suit their own circumstances, views and interpretations. Agrienvironmental policy has a history that needs to be investigated - not only in terms of an examination of the official archives, but also in terms of how such policies were understood, interpreted, followed or sometimes completely ignored by farmers on the ground. With this in mind, farmers should be recognised as knowledgeable actors, whose oral history can inform agrienvironmental policy for the future of the countryside.

INTERDISCIPLINARY SCIENCE REVIEWS, 2005, VOL. 30, N0. 1 
Both countryside issues and the collection of oral histories are undoubtedly very popular, and we should endeavour to make oral history into more than mere ornamentation or interesting anecdote, striving to complicate our understandings of the countryside as a social construct. In terms of policy relevance, such an oral history project has several strands. On one level, it can inform policymakers such as English Heritage and DEFRA on issues that will help them manage and deal with items, artefacts and entire landscapes that we have inherited from the past - animating and even challenging the more traditional forms of scientific or archive-based knowledge generation. However, it can also foster debate at a more general level, asking questions about who we are and why and how we value particular things. Furthermore, a historical angle can inform us on the development of policy over time, bringing a temporal understanding of the policy-forming position we are now in. With a more forward-looking frame of mind, however, oral histories may be able to animate and democratise policy, informing and helping to build policies for the future. Although oral histories are ostensibly about the past, their contexts are found in the present, while it is the future that their agendas are always aimed towards.

\section{ACKNOWLEDGEMENT}

This paper has been drawn from research funded through a UK Arts and Humanities Research Board 'Innovation Award' (AR15611). Any errors or misinterpretations are entirely the responsibility of the authors.

\section{NOTES}

1. B. Wynne: 'May the sheep safely graze? A reflexive view of the expert-lay knowledge divide', in Risk Environment and Modernity: Towards a New Ecology, (ed. S. Lash, B. Szerszynski and B. Wynne), 49; 1996, London, Sage.

2. J. Burchardt: Paradise Lost: Rural Idyll and Social Change in England Since 1800; 2002, London, Tauris; S. Seymour: 'Historical geographies of landscape', in Modern Historical Geographies, (ed. C. Nash and B. Graham), 193-217; 2000, Harlow, Longman.

3. C. Haskins: Rural Delivery Review: A Report on Governmental Policies in Rural England, 98; 2003, London, DEFRA. The same report, however, also praises DEFRA for its 'strong scientific base and an extensive operational function' (p. 19).

4. As well as Channel 4's Time Team, pop archaeology programming includes Meet the Ancestors, Time Flyers, The House Detectives, Two Men in a Trench and, more recently, Extreme Archaeology, not to mention programmes such as War Walks, Restoration, The 1940s House and many more.

5. Furze is a local name for gorse (Ulex Europaeus).

6. See for example A. G. Brown: 'Characterising prehistoric lowland environments using local pollen assemblages', Journal of Quaternary Science, 1999, 14, 585-594.

7. N. Evans, C. Morris and M. Winter: 'Conceptualizing agriculture: a critique of post-productivism as the new orthodoxy', Progress in Human Geography, 2002, 26, 313-332.

8. A. Irwin: Citizen Science: A Study of People, Expertise and Sustainable Development, 173; 1995, London, Routledge.

9. A. Callinicos: Making History: Agency, Structure, and Change in Social Theory; 2004, Leiden, Brill; R. G. Collingwood: The Idea of History; 1973, London, Oxford University Press.

10. R. Samuel: Theatres of Memory; 1994, London, Verso; P. Thompson: The Voice of the Past: Oral History; 1988, Oxford, Oxford University Press.

11. R. Samuel, p. 269 (see Note 10). Samuel was at the forefront of emancipatory history, which sought to give a voice to groups whose histories were absent from the privileged written record. He was therefore a keen advocate of oral history as an alternative line of inquiry.

INTERDISCIPLINARY SCIENCE REVIEWS, 2005, VOL. 30, N0. 1 
12. B. Short, C. Watkins, W. Foot and P. Kinsman: The National Farm Survey 1941-1943: State Surveillance and the Countryside in England and Wales in the Second World War, 2000, Oxford, CAB International.

13. The survey and accompanying maps are held at the National Archives, Kew, UK (NRA MAF 32 and MAF 73).

14. P. Thompson: The Voice of the Past: Oral History; 1988, Oxford, Oxford University Press.

15. A. Nevins: 'Oral history: how and why it was born', in Oral History: An Interdisciplinary Anthology, (ed. D. Dunaway and W. Baum), 7-30; 1996, London, Alta Mira.

16. Referred to in A. Green: 'Coffee and bun, Sergeant Bonnington and the tornado: myth and place in Frankton Junction', Oral History, 2000, 28, 26-34.

17. See for instance D. Hooke: Pre-Conquest Charter-Bounds of Devon and Cornwall; 1994, London, Boydell.

18. S. Jones: Early Medieval Sculpture and the Production of Meaning, Value and Place: The Case of Hilton of Cadboll; 2003, Edinburgh, Historic Scotland.

19. J. Fernandez and M. Herzfeld: 'In search of meaningful methods', in The Handbook of Methods in Cultural Anthropology, (ed. H. Bernard), 89-130; 1998, Walnut Creek, CA, Altamira Press.

20. See C. Holtorf: Monumental Past: The Life-Histories of Megalithic Monuments in Mecklenburg-Vorpommern (Germany); 2001, Toronto, CITD Press.

21. The Countryside Stewardship Scheme: Information and How to Apply; 2003, London, DEFRA.

22. For a discussion of 'invented traditions', see E. Hobsbawm: 'Inventing traditions', in The Invention of Tradition, (ed. E. Hobsbawm and T. Ranger); 1983, Cambridge, Cambridge University Press.

23. This is comparable to the findings of a contemporary study of ditch management on the Pevensey levels in Sussex, UK: J. Burgess, J. Clark and C. Harrison: 'Knowledges in action: an actor network analysis of a wetland agri-environment scheme', Ecological Economics, 2000, 32, 119-132.

24. For the one-dimensional narrative of hedgerow removal, see S. Petit, R. C. Stuart, M. K. Gillespie and C. J. Barr: 'Field boundaries in Great Britain: stock and change between 1984, 1990 and 1998', Journal of Environmental Management, 2003, 67, 229-238.

25. The Countryside Stewardship Scheme: Information and How to Apply, 28-29; 2002, London, DEFRA.

26. Typical here is T. Williamson: Hedges and Walls; 2002, London, National Trust, being written by an academic for a popular market; it estimates that between 1946 and 1970, around four and a half thousand miles of hedge were removed in England and Wales each year (p. 64).

27. For instance, see M. J. Watts: 'Enclosure: a modern spatiality of nature', in Envisioning Human Geographies, (ed. P. Cloke, P. Crang and M. Goodwin), 48-64, 49-52; 2004, London, Arnold.

28. For the present-centredness of heritage see B. Graham, J. Tonbridge and G. Ashworth: The Geography of Heritage; 1999, London, Arnold. See also D. C. Harvey: 'Heritage pasts and heritage presents: temporality, meaning and the scope of heritage studies', International Journal of Heritage Studies, 2001, 7, 319-338.

29. This phrase is drawn from John Berger's analysis of zoos, in which he sees animals as constituting 'a living monument to their own demise'. See J. Berger: About Looking; 1980, New York, NY, Pantheon.

David Harvey (d.c.harvey@exeter.ac.uk) is a lecturer in historical cultural geography in the Department of Geography at the University of Exeter. As well as working on oral histories of Devon's landscape, he is also currently investigating Methodist identities and community construction in Cornwall (1830-1930), with funding from the Leverhulme Trust, and the reception and interpretation of ancient monuments in Britain and Ireland (c. 1650-1950), in a project that has attracted funding from the British Academy.

Mark Riley is currently a research fellow in the AHRB Research Centre for Environmental History at the University of St Andrews. He was previously a research fellow in the Department of Geography at the University of Exeter working with David Harvey on the AHRB funded project 'Landscape archaeology and community in Devon: an oral history approach'. His $\mathrm{PhD}$ research, undertaken in the School of Geography at the University of Nottingham, took an ethnographic approach to the study of changing farm practices in the Peak District, challenging economic-centred models of agricultural change and problematising current conservation efforts. 